\title{
ARTIKELEN
}

\section{Zelfredzaamheid in detentie}

\section{Kritische kanttekeningen bij het systeem van promoveren en degraderen ${ }^{*}$}

\author{
Esther van Ginneken
}

\section{Inleiding}

De Dienst Justitiële Inrichtingen (DJI) hecht belang aan een goed leefklimaat in Nederlandse gevangenissen in de veronderstelling dat dit bijdraagt aan een veilige leef- en werkomgeving, een menswaardige behandeling, verantwoorde terugkeer naar de samenleving en de zelfredzaamheid van gedetineerden. ${ }^{1}$ Een positief leefklimaat is tevens een manier om invulling te geven aan het beginsel van minimale beperkingen, dat is vastgelegd in de Penitentiaire beginselenwet (PBW). Volgens het beginsel van minimale beperkingen zouden gedetineerden aan geen andere beperkingen onderworpen moeten worden 'dan die welke voor het doel van de vrijheidsbeneming of in het belang van de handhaving van de orde of de veiligheid in de inrichting noodzakelijk zijn' (art. 2 PBW). De factoren die het leefklimaat in justitiële inrichtingen bepalen, zijn: contacten binnen de inrichting, contacten met de buitenwereld, autonomie, dagbesteding, veiligheid en fysiek welbevinden. ${ }^{2}$

In dit artikel ga ik verder in op de focus van de DJI op het stimuleren van zelfredzaamheid van gedetineerden. Allereerst volgt een verklaring voor de nadruk die wordt gelegd op zelfredzaamheid en, in het verlengde daarvan, autonomie. Daarna bespreek ik het systeem van promoveren en degraderen als voorbeeld van (problematische) zelfredzaamheidsbevordering. De kritieken hierop worden verder uitgewerkt aan de hand van twee onderwerpen: (1) beperkingen in het zelfredzaam vermogen van gedetineerden, en (2) de beperkende, normatieve voorwaarden die aan zelfredzaamheid verbonden zijn. Tot slot gaat het artikel in op de vraag hoe autonomie bevorderd kan worden op een manier dat het uiting geeft aan het beginsel van minimale beperkingen.

* Dr. Esther van Ginneken is universitair docent Criminologie aan het Instituut voor Strafrecht en Criminologie van de Universiteit Leiden.

1 Dienst Justitiële Inrichtingen, Masterplan DJI 2013-2018, Den Haag: Dienst Justitiële Inrichtingen 2013.

2 M. Boone, M. Althoff \& F. Koenraadt, Het leefklimaat in justitiële inrichtingen, Den Haag: Wetenschappelijk Onderzoek- en Documentatiecentrum 2016. 


\section{Vrijheid en verantwoordelijkheid in detentie}

Autonomie vormt een onderdeel van het leefklimaat en wordt door Boone, Althoff \& Koenraadt beschreven als 'de mate waarin aan bewoners de mogelijkheid wordt gelaten zelf keuzes te maken'. ${ }^{3}$ Autonomie vereist de afwezigheid van externe belemmeringen (dwang of manipulatie), het vermogen om eigen beslissingen te kunnen nemen, en voldoende verschillende opties om uit te kiezen. ${ }^{4}$ Het is daarmee een ingewikkeld concept, zeker in de detentiecontext, aangezien een gevangenisstraf per definitie de autonomie beperkt. Niet voor niets wordt in het klassieke werk van Sykes the deprivation of autonomy besproken als een van de vijf pains of imprisonment. ${ }^{5}$

Om autonomie - als onderdeel van het leefklimaat - te bevorderen wordt de zelfredzaamheid van gedetineerden gefaciliteerd en gestimuleerd. ${ }^{6}$ Onder zelfredzaamheid wordt verstaan: 'het vermogen om zelfstandig algemene levensverrichtingen te doen' en 'het (zelf) organiseren van hulp en ondersteuning als dat nodig is bij dergelijke levensverrichtingen'. ${ }^{7}$ In relatie tot detentie is het uitgangspunt dat gedetineerden zo veel mogelijk zelfstandig functioneren en inrichtingspersoneel daarbij een zo beperkt mogelijke rol vervult. De DJI beoogt de zelfredzaamheid van gedetineerden op verschillende manieren te bevorderen, bijvoorbeeld door gebruik te maken van technologie zodat gedetineerden zich zelfstandig door de inrichting kunnen verplaatsen en bezoeken kunnen plannen (zoals in de recent geopende penitentiaire inrichting Zaanstad), of door de mogelijkheid te bieden om zelf maaltijden te bereiden.

Recentelijk hebben er ook meerdere pilots plaatsgevonden die gericht waren op het stimuleren van zelfredzaamheid. ${ }^{8}$ Gedetineerden die deelnamen aan deze pilots kregen extra privileges en mochten zich onder beperkter toezicht door de inrichting bewegen. Daarnaast waren er speciale baantjes met extra vrijheden gecreëerd. Voor deze pilots kwamen echter alleen gedetineerden in aanmerking die al in hoge mate zelfredzaam waren en een geschiedenis van goed gedrag hadden. Het is om deze reden aannemelijk dat de pilots weliswaar zelfredzaamheid faciliteerden bij gedetineerden die hiertoe het vermogen al hadden, maar niet bij

3 Boone, Althoff \& Koenraadt 2016, p. 75.

4 R. Claassen, Het huis van de vrijheid: Een politieke filosofie voor vandaag, Amsterdam: Ambo 2011.

5 G.M. Sykes, The society of captives: A study of a maximum security prison (3rd Princeton Paperback Ed., 1974), Princeton, NJ: Princeton University Press 1958.

6 Men kan omgekeerd ook stellen dat zelfredzaamheid kan worden bevorderd door gedetineerden autonomie te geven; dit is theoretisch meer voor de hand liggend. De twee concepten hebben een gecompliceerde verhouding; vooral in de praktijk van het gevangeniswezen zijn ze niet altijd van elkaar te onderscheiden.

7 T. Molleman, Zelfredzame gedetineerden: mogelijkheden binnen de muren, Den Haag: Wetenschappelijk Onderzoek- en Documentatiecentrum 2014, p. 5.

8 In PI Arnhem-Zuid, PI Heerhugowaard en PI Vught, zoals beschreven in B.J. de Jong, P.J.H. Willems \& A.E. Van Burik, Evaluatie pilots zelfredzaamheid gedetineerden, Woerden: Van Montfoort 2015; B.J. de Jong, P.J.H. Willems \& L.D.R. Torregrosa, Zelfredzaamheid in detentie: evaluatie van de pilot Participerende Detentie \& Maatschappelijke Arbeid PI Nieuwersluis, Woerden: Van Montfoort 2016; C. Farahi \& J. van de Rijt, 'Normalisatie en zelfredzaamheid binnen het gevangeniswezen', PROCES 2016, 2. 
gedetineerden met bijvoorbeeld beperkingen of gedragsproblemen. Uit evaluaties van de pilots bleek zinvol en zelfstandig werk als positief te worden ervaren door gedetineerden. ${ }^{9}$ Personeel en gedetineerden rapporteerden positieve veranderingen in zelfredzaamheid als gevolg van grotere vrijheden en verantwoordelijkheden binnen de pilot. ${ }^{10}$ Een verschuiving in de verhoudingen tussen personeel en gedetineerden van controle en dwang naar vertrouwen leidde tot grotere dynamische veiligheid, wat samenhing met wederzijds respect en een prettige (werk)sfeer. ${ }^{11}$ Hierbij moet opgemerkt worden dat de evaluaties zijn uitgevoerd op basis van kleine en selectieve groepen deelnemers.

Deze focus op zelfredzaamheid en autonomie resoneert met verwachtingen die worden uitgedragen onder de noemer van 'de participatiesamenleving'. Dit is sinds de troonrede van koning Willem-Alexander in 2013 een gangbare term in Nederland en duidt op een verschuiving van de verzorgingsstaat naar actief burgerschap. Hierbij ligt de nadruk op eigen verantwoordelijkheid en zelfredzaamheid van burgers in het oplossen van maatschappelijke vraagstukken als zorg, integratie en werkloosheid. Deze verantwoordelijkheid en zelfredzaamheid betekenen niet per definitie ook meer vrijheid, want de handelingsvrijheid wordt beperkt door een nauw kader van beoogde uitkomsten en daaraan gekoppeld wenselijk gedrag. Peeters en Drosterij spreken daarom van 'verstatelijkte verantwoordelijkheid', waarbij actief burgerschap wordt ingezet om beleidsambities te verwezenlijken. ${ }^{12}$ In de internationale context kan een vergelijkbare trend van responsabilisering worden gesignaleerd, met name ook ten behoeve van veiligheidsvraagstukken. ${ }^{13}$ In theorie is het stimuleren van zelfredzaamheid in de gevangenis dan ook een goed uitgangspunt voor resocialisatie, omdat eenzelfde houding wordt verwacht in de 'vrije' maatschappij, al moet hierbij uiteraard opgemerkt worden dat zelfredzaamheid in de gevangenis onvermijdelijk anders ingevuld zal moeten worden dan daarbuiten. In relatie tot de implementatie van beleid omtrent zelfredzaamheid in de gevangenis is echter te weinig aandacht voor de problemen van een dergelijke responsabilisering. In de volgende paragrafen zal nader worden ingegaan op problemen als gevolg van beperkingen in het zelfredzaam vermogen van gedetineerden en de beperkende, normatieve voorwaarden die aan gedrag worden gesteld. Beide kritiekpunten zijn van toepassing op het systeem van promoveren en degraderen.

9 De Jong, Willems \& Van Burik 2015.

10 De Jong, Willems \& Torregrosa 2016.

11 Farahi \& Van De Rijt 2016.

12 R. Peeters \& G. Drosterij, 'Verantwoordelijke vrijheid: responsabilisering van burgers op voorwaarden van de staat', Beleid en Maatschappij 2011, 2, p. 193.

13 D. Garland, 'The limits of the sovereign state: Strategies of crime control in contemporary society', The British Journal of Criminology 1996, 4, p. 445-471. 


\section{Systeem van promoveren en degraderen}

In 2014 is het systeem van promoveren en degraderen in werking getreden in Nederlandse penitentiaire inrichtingen. ${ }^{14}$ Op basis van dit systeem wordt bepaald of gedetineerden deelnemen aan het basis- of plusprogramma in de gevangenis. De achterliggende gedachte van het systeem is dat hiermee gedrag van gedetineerden tijdens detentie positief beïnvloed kan worden (door beloning van goed gedrag); de extra activiteiten en vrijheden voor gepromoveerde gedetineerden zijn erop gericht om hun kans op succesvolle re-integratie te verhogen. Het plusprogramma biedt 48 uur aan activiteiten, tegenover 43 uur in het basisprogramma. Bij binnenkomst in de gevangenis worden gedetineerden in de regel in het basisprogramma geplaatst. ${ }^{15}$ Hun gedrag wordt vervolgens op basis van een stoplichtmodel beoordeeld en kan na zes weken leiden tot promotie naar het plusprogramma. Er zijn zes gedragsdomeinen waarop gedetineerden worden beoordeeld: meewerken op de afdeling, omgaan met spanning en conflicten, sociaal functioneren, omgaan met hygiëne, zorg en begeleiding, middelengebruik, en meewerken aan re-integratie. Groen gedrag is gewenst gedrag, en gedetineerden die deze regels goed volgen komen in aanmerking voor promotie. Voorbeelden van groen gedrag zijn 'conflicten bespreekbaar maken en oplossen', 'een regelmatig dag-/ nachtritme hebben' en 'maken van huiswerk wanneer dit wordt gevraagd'. Oranje (dit kan beter) en rood (ongewenst) gedrag verhinderen promotie en kunnen leiden tot degraderen. Rood gedrag kan ook bestraft worden met disciplinaire maatregelen. Voorbeelden van oranje gedrag zijn 'rondhangen' en 'een kort lontje hebben' en van rood gedrag 'structureel huisregels niet naleven' en 'weigeren of manipuleren van urinecontrole'.

Gedetineerden in het plusprogramma hebben meer recht op sport, bezoek en onderwijs en komen tevens in aanmerking voor een (zeer) beperkt beveiligde inrichting of elektronische detentie in een later stadium van hun straf. De extra activiteiten in het plusprogramma hebben als doel om de gedetineerden intensiever te ondersteunen bij hun re-integratie; daarnaast hebben ze meer vrijheid tijdens activiteiten (bijvoorbeeld grotere verantwoordelijkheid tijdens arbeid) en op de afdeling (bijvoorbeeld uit de cel tussen activiteiten).

Gedrag wordt in eerste instantie beoordeeld door penitentiaire inrichtingswerkers op de afdeling en besproken in het multidisciplinaire overleg van een afdeling, die advies uitbrengt over het promoveren of degraderen van gedetineerden. De beslissingsbevoegdheid tot promoveren of degraderen ligt echter bij de directeur. Deze heeft enige discretionaire bevoegdheid, bijvoorbeeld in het beoordelen van ongewenst gedrag op het onderdeel 'zorg en begeleiding' van personen met een vastgestelde verstandelijke beperking of stoornis; hierbij geldt wel dat enkel personen met een aantoonbare bereidheid tot verbetering in aanmerking komen voor promotie.

Het systeem van promoveren en degraderen vloeit voort uit het programma 'Modernisering Gevangeniswezen', waarin gestreefd wordt naar 'een persoonsge-

15 Zelfmelders worden bij binnenkomst in detentie direct naar het plusprogramma gepromoveerd. 
richte aanpak gebaseerd op de levensloopbenadering'. ${ }^{16}$ Echter, de criminologie schetst juist een veel complexer beeld van het proces van stoppen met criminaliteit. ${ }^{17}$ Verder leunt het systeem op het principe van operante conditionering: het belonen van gewenst gedrag stimuleert dit gedrag, en negatieve consequenties ontmoedigen ongewenst gedrag. Hiermee wordt gedragsverandering op korte termijn beoogt; recidivevermindering is geen direct doel, maar het systeem is er wel op gericht om gedetineerden te stimuleren deel te nemen aan programma's die gericht zijn op recidivevermindering. ${ }^{18} \mathrm{Er}$ moet echter een aantal kritische kanttekeningen worden geplaatst bij de invoering van dit systeem.

Ten eerste is het bewijs over de werking van het achterliggende mechanisme van beloning en bestraffing ('contingency management') in gevangenissen zeer beperkt. De aanbeveling van een pilot en evaluatie in het rapport van Plaisier en Van Ditzhuijzen, ${ }^{19}$ dat ten grondslag ligt aan het systeem, is niet gerealiseerd. Hierdoor kan niet met zekerheid gesteld worden wat de gevolgen zijn van de implementatie van het stoplichtmodel. Evaluaties van een vorm van 'contingency management', de zogenaamde 'token economy'-programma's, waarbij goed gedrag beloond wordt met tokens die kunnen worden ingewisseld voor beloningen, suggereren dat een dergelijk beloningssysteem kan leiden tot gedragsverbetering op korte termijn. ${ }^{20}$ Deze resultaten kunnen echter niet worden gegeneraliseerd naar het systeem van promoveren en degraderen, omdat dit afwijkt van de principes van een 'token economy' en omdat succesvolle uitkomsten afhankelijk zijn van de programma-integriteit, oftewel de wijze waarop programma's worden geïmplementeerd.

Het systeem van Incentives and Earned Privileges (IEP) in Engeland en Wales is beter vergelijkbaar met het Nederlandse systeem van promoveren en degraderen. Het IEP-systeem kent gedetineerden ook privileges toe (en ontneemt ze) op basis van hun gedrag. De privileges verschillen echter deels met het Nederlandse systeem en er wordt onderscheid gemaakt tussen een entry, basic, standard en enhanced privilegeniveau. Voorbeelden van zaken waarin onder het IEP-systeem wordt gedifferentieerd zijn: bezoek, arbeidsloon, televisiegebruik en het dragen van eigen kleding. ${ }^{21}$ Een uitgebreide evaluatie van het IEP-systeem vond geen verbeteringen in het gedrag van gedetineerden, maar signaleerde juist een verslechtering in de verhouding met personeel. ${ }^{22}$ Dit kan mogelijk verklaard worden door de inconsistente implementatie en grote discretionaire ruimte van personeel in het toekennen en ontnemen van privileges. Na de implementatie van het IEP-

16 Kamerstukken II 2010/11, 29270, 52, p. 2.

17 M. Boone, 'Schurende mensbeelden: het verantwoordelijk stellen van gedetineerden voor hun resocialisatie', in: F. de Jong \& R.S.B. Kool (red.), Relaties van gezag en verantwoordelijkheid: strafrechtelijke ontwikkelingen, Den Haag: Boom Lemma uitgevers 2012, p. 291-306.

18 J. Plaisier \& J. van Ditzhuijzen, Stimuleren en ontmoedigen van gedetineerden, Amsterdam: Impact 2009.

19 Plaisier \& Van Ditzhuijzen 2009.

20 P. Gendreau e.a. 'Making prisoners accountable: Are contingency management programs the answer?', Criminal Justice and Behavior 2014, 9, p. 1079-1102.

21 Prison Service Instruction 30/2013.

22 A. Liebling e.a., Incentives and earned privileges for prisoners - An evaluation (Research findings nr. 87), Londen: Home Office Research, Development and Statistics Directorate 1999. 
systeem voelden gedetineerden zich minder rechtvaardig bejegend door personeel. Ook in later onderzoek is opgemerkt dat er veel onzekerheid bestaat onder gedetineerden over hoe hun gedrag wordt geïnterpreteerd en hoe ze vooruit kunnen komen in het systeem. ${ }^{23}$ Hoewel er in Engeland en Wales inmiddels veel ervaring is met het systeem, lijken gedetineerden zich nog steeds niet rechtvaardig behandeld te voelen in de manier waarop personeel privileges toekent en ontneemt. ${ }^{24}$ Uit de Engelse ervaring kan dus afgeleid worden dat een privilegesysteem mogelijk averechts kan werken indien de rechtvaardige toepassing ervan niet gewaarborgd is. Er is geen onderbouwing dat de beoogde gedragsverbeteringen bewerkstelligd kunnen worden.

De tweede kanttekening die bij de invoering van het systeem van promoveren en degraderen geplaatst kan worden, betreft de miskenning van beperkingen en behoeften van de populatie. Het moet ter discussie worden gesteld of het systeem werkelijk bijdraagt aan het bevorderen van de zelfredzaamheid van gedetineerden, omdat het uitgangspunt van de rationele mens - die handelt op basis van een kosten-batenafweging - niet overeenkomt met de realiteit. Het is een positieve ontwikkeling dat er in recente jaren binnen het gevangeniswezen meer aandacht is voor zogeheten niet-kunners (gedetineerden met extra zorgbehoeften). ${ }^{25}$ Ook in de Handleiding Toetsingskader promoveren en degraderen wordt rekening gehouden met de beperkingen van deze groep gedetineerden. ${ }^{26}$ Echter, er wordt ook gesteld dat het lastig is 'om "niet kunners" te herkennen omdat ze vaak ook niet goed communiceren en daarmee hun onvermogen verbergen'. ${ }^{27}$ Onderzoek naar licht verstandelijke beperkingen (LVB) onder gedetineerden (zie ook de volgende paragraaf) suggereert dat de groep niet-kunners groter is dan door personeel wordt ingeschat. ${ }^{28}$ Aangezien er thans (nog) geen gebruik wordt gemaakt van een instrument om een LVB vast te stellen, is er een groot risico dat 'niet willen' en 'niet kunnen' in de praktijk moeilijk te onderscheiden zijn. Daarnaast is zelfredzaam vermogen ook situationeel variabel: stress, mentale vermoeidheid en financiële zorgen kunnen rationeel en zelfredzaam gedrag in de weg staan. ${ }^{29}$

Hoewel het systeem erop gericht is om succesvolle re-integratie na detentie te bevorderen, sluit het niet aan bij de complexe behoeften van de populatie. Enkel gedetineerden die verantwoordelijk gedrag tonen komen in aanmerking voor

23 B. Crewe, 'Soft power in prison: Implications for staff-prisoner relationships, liberty and legitimacy', European Journal of Criminology 2011, 6, p. 455-468.

24 Z. Khan, 'An exploration of prisoners' perceptions of the Incentives and Earned Privileges (IEP) scheme: The role of legitimacy', Prison Service Journal 2016, 11, p. 11-16.

25 R. Krabbendam \& P. Nelissen, 'Het gevangeniswezen op de schop: de ambities van het programma Modernisering Gevangeniswezen', Sancties 2012, 225, p. 225-241.

26 Dienst Justitiële Inrichtingen, Handleiding Toetsingskader promoveren en degraderen, Den Haag: Dienst Justitiële Inrichtingen 2013.

27 Dienst Justitiële Inrichtingen 2013, Handleiding Toetsingskader. p. 16.

28 H.L. Kaal e.a., De problematiek van gedetineerden met een licht verstandelijke beperking in het gevangeniswezen, Tilburg: Tilburg University 2011.

29 A. Mani e.a., 'Poverty impedes cognitive function', Science 2013, 976, p. 976-981; A.K. Shah, S. Mullainathan \& E. Shafir, 'Some consequences of having too little', Science 2012, 682, p. 682-685; Wetenschappelijke Raad voor het Regeringsbeleid, Weten is nog geen doen: een realistisch perspectief op redzaamheid, Den Haag: Wetenschappelijke Raad voor het Regeringsbeleid 2017. 
bepaalde vrijheden en resocialisatieactiviteiten. 'Interne vrijheden en re-integratieactiviteiten kunnen worden verdiend als de gedetineerde heeft aangetoond dat hij kan omgaan met verantwoordelijkheden en zich wil inzetten voor gedragsverandering. ${ }^{30}$ Boone heeft elders al beargumenteerd dat het resocialisatiebeginsel wordt aangetast doordat resocialisatieactiviteiten niet langer voor iedereen toegankelijk zijn. ${ }^{31}$ Het bestraffen van onverantwoordelijk gedrag is 'contra-intuïtief aan het idee dat resocialiserende inspanningen juist gericht zijn op het aanleren van verantwoordelijk gedrag. ${ }^{32}$ Het huidige systeem vergroot hiermee de ongelijkheid als gevolg van verschillen in zelfredzaam vermogen (zoals in de volgende paragraaf uiteen wordt gezet) en beperkt daarnaast ook de kansen op een succesvolle terugkeer in de maatschappij van gedetineerden die hier de meeste begeleiding bij nodig hebben. Het is bijvoorbeeld bekend dat bezoek tijdens detentie het sociaal kapitaal van gedetineerden kan verstevigen en daarmee kan bijdragen aan lagere recidive. ${ }^{33}$ Dit wordt ondermijnd door het systeem van promoveren en degraderen, omdat gedetineerden in het basisprogramma een uur minder per week bezoek kunnen ontvangen; het druist in tegen wetenschappelijke kennis om juist gedetineerden die onvoldoende zelfredzaam zijn uit te sluiten van bezoek, terwijl zij hier juist het meest van zouden kunnen profiteren.

Gezien de criminologische literatuur zou verantwoordelijkheidsbesef geen voorwaarde voor deelname moeten zijn, maar wel kunnen dienen ter vormgeving van een persoonsgericht resocialisatietraject. ${ }^{34}$ Op deze manier kunnen zij die niet zelfstandig verantwoordelijkheid kunnen nemen, daartoe werkelijk geholpen worden. Hierbij moet voorkomen worden dat een helpende aanpak een dwingende aanpak wordt; de overheid kiest in sommige domeinen voor een repressieve aanpak indien burgers verzaken om hun verantwoordelijkheid te nemen om complexe vraagstukken mee op te lossen. ${ }^{35}$

Daarnaast zijn er nog meer kanttekeningen bij de invoering van het systeem te plaatsen. Zo doet de huidige aanpak afbreuk aan het beginsel van minimale beperkingen. Het is zeer de vraag of het onthouden van bepaalde privileges, zoals een uur extra bezoek, in het belang is van de handhaving van orde of veiligheid. Integendeel: activiteiten buiten de cel en sociale contacten kunnen een belangrijk copingmechanisme zijn en daardoor juist bijdragen aan orde en veiligheid. ${ }^{36}$ Veel

33 W.D. Bales \& D.P. Mears, 'Inmate Social Ties and the Transition to Society: Does Visitation Reduce Recidivism?', Journal of Research in Crime and Delinquency 2008, 3, p. 287-321; I. BruntonSmith \& D.J. McCarthy, 'The effects of prisoner attachment to family on re-entry outcomes: A longitudinal assessment', British Journal of Criminology 2017, 2, p. 463-482; G. Duwe \& V. Clark, 'Blessed be the social tie that binds: The effects of prison visitation on offender recidivism', Criminal Justice Policy Review 2013, 3, p. 271-296; D.P. Mears, J.C. Cochran \& W.D. Bales, 'Gender differences in the effects of prison on recidivism', Journal of Criminal Justice 2012, 5, p. 370-378.

34 Boone 2012.

35 Peeters \& Drosterij 2011.

36 M.A. Hutton, 'Prison visits and desistance: A human rights perspective', in: E.L. Hart \& E.F.J.C. van Ginneken (red.), New perspectives on desistance: Empirical and theoretical developments, Londen: Palgrave Macmillan 2017. 
van de gestelde gedragseisen binnen het stoplichtmodel hebben geen verband met veiligheid, zoals de eisen die vallen onder het 'omgaan met hygiëne, zorg en begeleiding' of het 'meewerken aan re-integratie'. Of het verschil in bezoekuren tussen het basis- en plusprogramma wordt gezien als bestraffing of beloning is slechts een semantische kwestie (op papier is het plusprogramma een beloning) die irrelevant is voor de beleving van gedetineerden.

Een dergelijke instrumentele benadering van bezoek ondermijnt bovendien het idee dat contact met familie een recht is. In de Penitentiaire beginselenwet is vastgelegd dat een gedetineerde het recht heeft om ten minste één uur per week bezoek te ontvangen (art. 38 lid 1 PBW). Door extra bezoekuren toe te kennen aan gedetineerden in het plusprogramma wordt een recht tegelijkertijd gebruikt als beloning voor gewenst gedrag. Het recht op contact met de buitenwereld is ook opgenomen in het Europese Verdrag voor de rechten van de mens (EVRM). Artikel 8 van dit verdrag omvat het recht op eerbiediging van privé-, familie- en gezinsleven en stelt dat eenieder recht heeft 'op respect voor zijn privé leven, zijn familie- en gezinsleven, zijn woning en zijn correspondentie' (art. 8 lid 1 EVRM). Inmenging van de overheid, waaronder een gevangenis, is toegestaan in de omstandigheden die uiteen zijn gezet in artikel 8 lid 2 EVRM, waaronder bescherming van de veiligheid en het voorkomen van wanordelijkheden en strafbare feiten. Zoals hiervoor beargumenteerd, is het gebruik van bezoek als beloning binnen het stoplichtmodel niet in overeenstemming met bezoek als (relatief) mensenrecht.

Het gedragsafhankelijk maken van bezoek heeft niet alleen gevolgen voor de gedetineerde, maar ook voor diens familie. Immers, het recht op eerbiediging van een familie- en gezinsleven geldt ook voor de partner, kinderen en ouders van een gedetineerde. Zij worden in het huidige beleid gereduceerd tot instrument om gewenst gedrag van gedetineerden te stimuleren; een kritiek die Hutton ook heeft verwoord met betrekking tot het IEP-systeem in Engeland en Wales. ${ }^{37}$

\section{Beperkt zelfredzaam vermogen van gedetineerden}

De beleidsmatige nadruk op zelfredzaamheid veronderstelt dat de meeste mensen zelfredzaam kunnen zijn en dat dit voor iedereen een wenselijk uitgangspunt is. Dit is een problematische aanname voor de maatschappij in het algemeen, ${ }^{38}$ maar in het bijzonder voor de gedetineerdenpopulatie.

Ten eerste is de problematiek onder gedetineerden zodanig complex dat er een vage scheidslijn is tussen het niet kunnen en niet willen nemen van verantwoordelijkheid voor bepaald gedrag. De gedetineerdenpopulatie wordt gekenmerkt door complexe problematiek, waaronder (licht) verstandelijke beperkingen, drugs- en 
alcoholverslaving, financiële, relationele en psychische problemen. ${ }^{39}$ Deze problemen kunnen de cognitieve capaciteit om te plannen en impulsief gedrag te beheersen danig beperken; ${ }^{40}$ verschillende studies hebben aangetoond dat onder andere financiële zorgen een negatieve invloed hebben op het vermogen om weloverwogen keuzes te maken en zelfcontrole uit te oefenen. ${ }^{41}$ Dit raakt aan een belangrijke kritiek op het responsabiliseringsdiscours, waarin de oorzaak en oplossing voor crimineel gedrag bij het individu worden gezocht: er is te weinig oog voor de rol van omstandigheden die de mogelijkheden tot positieve verandering beperken. Onder gedetineerden is de motivatie om een 'normaal' leven te leiden vaak wel aanwezig, maar ontbreekt het - zeker na vrijlating - vaak aan kansen en sociaal en economisch kapitaal om deze wens te realiseren. ${ }^{42}$ Nadruk op zelfstandigheid en eigen verantwoordelijkheid zonder baankans of ondersteuning bij problemen kan hierdoor leiden tot frustratie en averechtse effecten.

Een LVB hangt ook samen met een beperkt zelfredzaam vermogen. Gedetineerden met een LVB zijn minder goed in staat om zelfstandig zaken te regelen, problemen actief op te lossen en rapporten (voor het overtreden van regels) te vermijden. ${ }^{43}$ Doordat deze gedetineerden moeite hebben met (sociale) informatieverwerking, ervaren zij situaties eerder als stressvol en komen ze vaker in conflictsituaties terecht. Naar alle waarschijnlijkheid is er een aanzienlijke groep gedetineerden met een LVB, maar dit is tot op heden niet systematisch in kaart gebracht en wordt ook niet getest bij binnenkomst in de gevangenis. ${ }^{44}$ Een pilotstudie voor een screeningsinstrument voor LVB (SCIL) doet vermoeden dat meer dan een derde van de Nederlandse gedetineerden een LVB heeft. ${ }^{45}$ Vooralsnog wordt dit screeningsinstrument niet gebruikt in de dagelijkse detentiepraktijk. Omdat er hierdoor weinig zicht is op LVB-problematiek onder gedetineerden, kan er ook moeilijk passende ondersteuning worden geboden. Vaak is de enige zicht-

39 A. Brons e.a., 'Psychische klachten bij mannelijke gedetineerden', Tijdschrift voor Criminologie 2013, 3, p. 241-258; E. Bulten \& H. Nijman, 'Veel psychiatrische stoornissen onder gedetineerden op reguliere afdelingen van penitentiaire inrichtingen', Nederlands Tijdschrift voor Geneeskunde 2009, A634, p. 1-6; Kaal e.a. 2011; J. Verhagen, Gedetineerden ontmaskerd. Hoe in Nederland over gedetineerden wordt gedacht en hoe het werkelijk 'zit', Veenhuizen: Nationaal Gevangenismuseum 2011.

40 J. Meijers e.a., 'Prison brain? Executive dysfunction in prisoners', Frontiers in Psychology 2015, 2, p. 2-7.

41 Mani e.a. 2013; Shah, Mullainathan \& Shafir 2012.

42 E.L. Hart, 'Women prisoners and the drive for desistance: Capital and responsibilization as a barrier to change', Women \& Criminal Justice 2017, 3, p. 151-169; M. Soyer, 'The imagination of desistance: A juxtaposition of the construction of incarceration as a turning point and the reality of recidivism', British Journal of Criminology 54/1, p. 91-108; S. Wright, 'Narratives of punishment and frustrated desistance in the lives of repeatedly criminalised women', in: Hart \& Van Ginneken (red.) 2017.

43 Kaal e.a. 2011; J. Talbot, Prisoners' voices: Experiences of the criminal justice system by prisoners with learning disabilities and difficulties, Londen: Prison Reform Trust 2008.

44 H.L. Kaal, Beperkt en gevangen? De haalbaarheid van prevalentieonderzoek naar verstandelijke beperking in detentie, Den Haag: Wetenschappelijk Onderzoek- en Documentatiecentrum 2010; Kaal e.a. 2011.

45 H.L. Kaal, Evaluatie pilot 'Screenen voor LVB in het gevangeniswezen', Leiden: Hogeschool Leiden 2013. 
bare uiting van een LVB ongewenst gedrag, maar bij het belonen en bestraffen van gedrag worden dergelijke onderliggende beperkingen niet mee in aanmerking genomen. Dit probleem wordt versterkt wanneer zelfredzaamheid als gedragsstandaard wordt gesteld, zoals het geval is binnen het systeem van promoveren en degraderen, omdat mensen met een LVB juist ondersteuning nodig hebben. Als dit niet herkend wordt, kan dit leiden tot frustratie en normafwijkend gedrag. Daarnaast lopen gedetineerden met een LVB een grotere kans om slachtoffer te worden van pesterijen en misbruik door medegedetineerden, omdat ze meer moeite lijken te hebben om voor zichzelf op te komen. ${ }^{46}$

Een tweede probleem van de nadruk op zelfredzaamheid zonder oog voor vermogen is dat dit leidt tot grotere ongelijkheid. Zo heeft onderzoek naar burgerparticipatie in Rotterdam uitgewezen dat er minder burgerparticipatie is in arme en etnisch diverse wijken. ${ }^{47}$ In combinatie met een overheid die zich terugtrekt uit het sociale domein, waardoor er minder publieke voorzieningen zijn, zal de ongelijkheid tussen geprivilegieerde en kwetsbare burgers groeien. 'Juist in kwetsbare stadsbuurten met veel armoede en etnische diversiteit zijn bewoners minder in staat om de gevolgen van een zich terugtrekkende overheid door actieve burgerparticipatie op te vangen. ${ }^{48}$ Eenzelfde risico geldt voor detentie.

Gedetineerden die voldoende economisch, cultureel en sociaal kapitaal hebben, kunnen dit aanwenden om vooruit te komen in het systeem. Zij zijn bijvoorbeeld beter in staat om te profiteren van onderwijs en cursussen, om formulieren in te vullen om bepaalde zaken gedaan te krijgen, en om op constructieve wijze problemen op te lossen. Doordat deze eigenschappen binnen het systeem van promoveren en degraderen beloond worden, kan deze groep relatief 'kapitaalkrachtige' gedetineerden privileges verwerven waarmee ze hun tijd nog zinvoller kunnen besteden en tegelijkertijd kunnen werken aan hun resocialisatie. Gedetineerden die niet over dergelijk kapitaal beschikken, zullen minder snel vooruitkomen in het systeem, waardoor hun achterstand nog groter wordt. Een concreet voorbeeld van ongelijkheid in detentie zien we in relatie tot het zelf kunnen koken. Standaard krijgen gedetineerden dagelijks een magnetronmaaltijd die zij zelf kunnen opwarmen. Op veel afdelingen is er ook de mogelijkheid om zelf te koken. Gedetineerden moeten hiervoor echter zelf de ingrediënten bestellen en betalen, waardoor het voor gedetineerden zonder financiële steun van buiten vaak geen realistische optie is. ${ }^{49}$ Hoewel zelf koken een voor de hand liggende vorm van zelfredzaamheid is, kunnen vooralsnog alleen enigszins geprivilegieerde gedetineerden deze mogelijkheid benutten.

G. Engbersen, E. Snel \& M. Hart, Mattheüs in de buurt: Over burgerparticipatie en ongelijkheid in steden, Rotterdam: Kenniswerkplaats Leefbare Wijken 2015.

Engbersen, Snel \& Hart 2015, p. 3.

Met arbeid verdienen gedetineerden een basisuurloon van $€$ 0,76 (art. 2 lid 2 Regeling Arbeidsloon Gedetineerden). Gedetineerden kunnen normaal gesproken (afgezien van pilots) maximaal één dagdeel per dag - oftewel 20 uur per week - werken. Van hun loon moeten ook bijvoorbeeld sigaretten en de huur van een tv worden bekostigd. Zie ook K. Beyens \& M. Boone, 'Zeg maar Henk tegen de chef: Ervaringen met het Belgische detentieregime in de PI Tilburg, Den Haag: Boom Lemma uitgevers 2013. 
Kort samengevat, de nadruk op zelfredzaamheid in detentie miskent het belang van factoren die buiten machte van het individu van invloed zijn op gedrag en zelfredzaam vermogen. Wangedrag is niet noodzakelijk een goede graadmeter voor het niet willen nemen van verantwoordelijkheid; het kan namelijk ook een uiting zijn van frustratie als gevolg van een beperkt zelfredzaam vermogen.

\section{Het burgerschapsideaal als beperking van autonomie}

Een ander probleem van de focus op zelfredzaamheid in de huidige vorm is de beperkende voorwaarden die hieraan worden gesteld: van burgers en gedetineerden wordt verwacht dat zij hun 'autonomie' op een bepaalde manier aanwenden, waardoor hun vrijheid in feite wordt beperkt. Deze paradox van zelfredzaamheid als voorwaarde, maar wel onder bepaalde (en beperkende) voorwaarden, wordt ook door Schuilenburg besproken in relatie tot veiligheid en vrijheid. ${ }^{50} \mathrm{Hij}$ spreekt over een dubbele clausulering, waarbij de overheid de voorwaarde stelt dat burgers deels verantwoordelijk zijn om de politie te ondersteunen bij veiligheidstaken in de buurt, en zij bovendien voorwaarden verbindt aan die verantwoordelijkheid. Dit uit zich in toenemende surveillance en controle, zodat 'risicoburgers' (die de veiligheid bedreigen) tijdig gesignaleerd kunnen worden. De paradox ligt dus in de toenemende verantwoordelijkheid van burgers om complexe vraagstukken mee op te lossen zonder het vertrouwen dat zij deze verantwoordelijkheid op de 'juiste' manier kunnen dragen.

Eenzelfde voorwaardelijke autonomie is zichtbaar in het gevangeniswezen. Gedetineerden kunnen meer vrijheden verdienen door zich goed te gedragen. Het vertrouwen dat zij verantwoordelijk met vrijheid om kunnen gaan is dus niet het uitgangspunt bij binnenkomst in detentie, maar een beloning voor normconform gedrag en een aangetoonde motivatie om aan re-integratie mee te werken. Dit illustreert een verandering in de manier waarop de doelstellingen van de DJI door de jaren heen in de praktijk zijn gebracht. Het bestempelen van bepaalde resocialisatieactiviteiten als voorrecht draagt bij aan de versobering van het detentieregime die het huidige gevangenisbeleid karakteriseert; ${ }^{51}$ hierbij lijken het beginsel van minimale beperkingen en het resocialisatiebeginsel minder nadrukkelijk tot uiting te komen.

Aan de begrippen 'vrijheid' en 'autonomie', zoals deze zowel in de vrije maatschappij als in de gevangenis gehanteerd worden, ligt een nauw normatief kader van 'goed burgerschap' ten grondslag. Het betreft hier geen 'negatieve vrijheid', die door Berlin wordt gedefinieerd als de vrijheid van externe belemmeringen en dwang. ${ }^{52}$ Dergelijke negatieve vrijheid faciliteert in de praktijk een pluralistische invulling op basis van individuele normen en waarden zolang deze de vrijheid van anderen respecteert. 'Positieve vrijheid' daarentegen definieert Berlin als de vrijheid tot zelfontplooiing naar een ideaalbeeld van de samenleving. Deze vrijheid

50 M. Schuilenburg, 'Positieve veiligheid en positieve vrijheid: meningen van wijkbewoners in Rotterdam-Zuid over Buurt Bestuurt', Tijdschrift over Cultuur \& Criminaliteit 2016, 3, p. 53-70.

51 Dienst Justitiële Inrichtingen 2013, Masterplan.

52 I. Berlin, Twee opvattingen van vrijheid (vertaling: T. Ausma), Amsterdam: Boom 1958. 
gaat samen met het idee dat men bepaalde mogelijkheden en vaardigheden moet hebben om autonoom te kunnen zijn. Volgens Berlin is positieve vrijheid problematisch, omdat hiervoor een oordeel over iemands autonome capaciteit moet worden geveld, in het licht van het ideale maatschappijbeeld, wat de deur openstelt voor indoctrinatie en dictatuur.

Door de directe en indirecte sturing van wenselijk gedrag kan de zogenaamde autonomie juist als onderdrukkend en paternalistisch worden ervaren. We kunnen dit herleiden naar de neoliberale opvatting dat vrijheid een verantwoordelijkheid van het individu is om zich in te zetten voor de algemene zaak; hiermee is vrijheid een vorm van bestuursrationaliteit. ${ }^{53}$ Claassen stelt dat er in dit geval niet van (positieve) vrijheid als autonomie kan worden gesproken; autonomie vereist weliswaar zelfbepaling, maar ook onafhankelijkheid van dwang en voldoende verschillende opties om het leven vorm te geven. ${ }^{54}$ Hij maakt onderscheid tussen positieve vrijheid (het autonomie-ideaal) en het welzijnsideaal (of verheffingsideaal); in het eerste geval voorziet de staat in het vervullen van de voorwaarden voor het autonoom functioneren van burgers, in het laatste geval tracht de staat burgers een bepaalde levenswijze op te leggen. Het nauwe normatieve kader van 'goed burgerschap' beperkt - uiteindelijk met dwangmiddelen - de vrijheid van burgers. Ik zou hier daarom willen spreken van het burgerschapsideaal. Bij het autonomie-ideaal daarentegen heeft de staat als doel om burgers vrij te maken, zodat ze hun leven binnen de kaders van de wet en beschermd door de rechtsstaat naar eigen inzicht kunnen invullen.

Het stimuleren van zelfredzaamheid in detentie middels het systeem van promoveren en degraderen is een uiting van het burgerschapsideaal. De responsabilisering van gedetineerden wordt vergezeld van een palet aan gedragsverwachtingen en -beperkingen. Crewe beschrijft een neopaternalistische trend waarbij de 'hard power' van personeel heeft plaatsgemaakt voor 'soft power', oftewel dwang en machtsuitoefening zijn vervangen door gedragssturing. ${ }^{55}$ De grenzen aan gedrag die voorheen helder waren, zijn hierdoor vervaagd; echter, gedetineerden die zich niet conformeren aan de (soms impliciete) gedragsnormen, zullen hierdoor in het systeem op een achterstand komen. Tevens veroorzaakt de onzekerheid over waar de grenzen liggen en wat de verwachtingen zijn, nieuwe pains of imprisonment, die ervoor zorgen dat detentie als benauwend (tight) wordt ervaren. ${ }^{56}$ Gedrag van gedetineerden dat buiten de normatieve kaders van goed burgerschap in de gevangenis valt, wordt aangemerkt als wangedrag, of 'dit kan beter'-gedrag. Aan dergelijk gedrag kunnen verschillende oorzaken ten grondslag liggen. Eerder in dit artikel is al besproken dat wangedrag een uiting kan zijn van frustratie als gevolg van een beperkt zelfredzaam vermogen in een omgeving die bepaalde eisen aan zelfstandigheid stelt. Wangedrag kan echter ook geïnterpreteerd worden als een vorm van zelfredzaamheid die het dominante normenpatroon verwerpt. De

53 W. Schinkel \& F. van Houdt, 'Besturen door vrijheid: neoliberaal communitarisme en de verantwoordelijke burger', Bestuurskunde 2010, 12, p. 14.

54 Claassen 2011.

55 B. Crewe, The prisoner society, Oxford: Oxford University Press 2009; Crewe 2011.

56 B. Crewe, 'Depth, weight, tightness: Revisiting the pains of imprisonment', Punishment \& Society 2011, 5, p. 509-529. 
georganiseerde criminaliteit is een voorbeeld van een gemeenschap met een alternatief normenpatroon, maar ook binnen de gevangenismuren heersen vaak alternatieve gedragscodes. ${ }^{57}$ Verschillende onderzoeken werpen licht op de manieren waarop gedetineerden pogen hun autonomie te behouden; wangedrag kan daarmee in sommige gevallen ook een vorm van verzet zijn tegen de restricties van het regime. ${ }^{58}$

De reactie op wangedrag in detentie is straffen: het ontnemen van privileges en/ of afzondering (in eigen cel of strafcel). Met beide maatregelen wordt de negatieve vrijheid van gedetineerden verder beperkt, waardoor in twijfel kan worden getrokken of zelfredzaam gedrag hiermee wordt gestimuleerd. Dit geldt zeker voor gedetineerden waarbij wangedrag te wijten is aan een beperkt keuzevermogen.

\section{Van zelfredzaamheid naar autonomie}

In dit artikel is een aantal specifieke kritiekpunten op het systeem van promoveren en degraderen nader uitgewerkt die de doeltreffendheid van het systeem in twijfel trekken. Echter, men moet het kind niet weggooien met het badwater. Eerder in dit artikel verwees ik al naar een aantal veelbelovende pilots binnen Nederlandse penitentiaire inrichtingen; ook internationaal onderzoek geeft handvatten voor een toekomstvisie waarin autonomie (in plaats van zelfredzaamheid) centraal staat. Dit betekent in feite een verschuiving van een burgerschapsideaal naar een autonomie-ideaal, waarbij de gevangenis een voorwaardenscheppende functie voor zelfredzaamheid vervult. Dit vereist twee grote veranderingen: ten eerste moeten de grenzen van negatieve vrijheid leidend worden voor belonen en bestraffen, en ten tweede is er meer aandacht nodig voor verschillen in zelfredzaam vermogen.

Binnen het huidige systeem van promoveren en degraderen lopen 'harde' en 'zachte' gedragsnormen door elkaar. Onder harde gedragsnormen vallen de regels aangaande orde en veiligheid, waarvan overtreding (meestal) een strafbaar feit is, zoals geweldpleging, bedreiging en handel in verdovende middelen. Zachte gedragsnormen daarentegen hebben betrekking op het vervullen van een burgerschapsideaal dat uitstijgt boven gehoorzaamheid aan de wet. Hieronder vallen, onder andere, het actief meewerken aan re-integratie, uiterlijke verzorging en prosociaal gedrag. Op overtreding van harde gedragsnormen zouden duidelijke sancties moeten staan die op rechtvaardige wijze worden toegepast, met als hoofddoel het waarborgen van veiligheid en orde in detentie. Hiermee worden de grenzen van negatieve vrijheid aangegeven. Voor het stellen en controleren van zachte gedragsnormen zou de verantwoordelijkheid hoofdzakelijk bij de (gemeenschap van) gedetineerden moeten liggen.

57 J. Irwin \& D. Cressey, 'Thieves, convicts and the inmate culture', Social Problems 1962, 2, p. 142-155; Sykes 1958.

58 M. Bosworth, Engendering resistance: Agency and power in women's prisons, Aldershot: Ashgate 1990; T. Ugelvik, Power and resistance in prison: Doing time, doing freedom, Basingstoke: Palgrave Macmillan 2014. 
Door het verantwoordelijk maken van de gemeenschap voor de leefbaarheid overstijgt het voldoen aan zachte gedragsnormen het individueel belang. Terwijl de focus op zelfredzaamheid en het systeem van promoveren en degraderen het eigenbelang benadrukken, staat bij zogenoemde gedeelde autonomie juist het belang van de gemeenschap centraal. Gedetineerden profiteren niettemin ook individueel van een gemeenschap waarvan de leden zich houden aan gedragsnormen die door de groep worden onderschreven. Doordat de normen in overleg worden bepaald, is aannemelijk dat de gepercipieerde legitimiteit van normhandhaving hoger is dan wanneer de normen van bovenaf worden bepaald en opgelegd. Een dergelijke vorm van zelfbestuur kan verder worden uitgewerkt aan de hand van het concept spatial autonomy. ${ }^{59}$

Vier elementen bepalen de mate van spatial autonomy: flexibiliteit, vrijblijvendheid, eigenaarschap en verantwoordelijkheid. ${ }^{60}$ Flexibiliteit omvat de vrijheid om de leefomgeving naar eigen en collectief inzicht in te richten en aan te passen aan de gewenste functies. Een hoge mate van flexibiliteit betekent dat gedetineerden in overleg de bestemming van ruimtes kunnen bepalen, alsmede de huisregels en het dagprogramma. De mate van vrijblijvendheid bepaalt in hoeverre gedetineerden verplicht zijn om aan het dagprogramma mee te doen, maar ook of ze bijvoorbeeld kunnen bepalen om alleen te eten in plaats van met medegedetineerden. Het naleven van huisregels valt hier echter niet onder. Eigenaarschap is nauw gelinkt aan flexibiliteit en heeft betrekking op de mate waarin gedetineerden eigenaar zijn van hun eigen cel en de gemeenschappelijke ruimte en, in het verlengde daarvan, kunnen bepalen hoe die ruimtes gebruikt worden. Dit heeft ook gevolgen voor de verantwoordelijkheid voor hoe de ruimtes worden gebruikt en de mate waarin gedetineerden aan elkaar rekenschap moeten afleggen over hun gedrag en het (niet) naleven van de huisregels.

Bird illustreert het concept van spatial autonomy aan de hand van een documentanalyse van de Barlinnie Special Unit, zoals die tussen 1973 en 1994 opereerde binnen de Barlinnie-gevangenis in Schotland. ${ }^{61}$ Deze unit herbergde een beperkt aantal langgestrafte gedetineerden met gedragsproblemen. Hoewel zij in de normale populatie moeilijk te handhaven waren, waren er onder het regime in de unit positieve gedragsveranderingen waarneembaar, die volgens Bird te danken waren aan het respect voor menselijke waardigheid dat de hoge mate van spatial autonomy vergezelde. ${ }^{62}$ De gedetineerden voelden zich hierdoor niet langer genoodzaakt om zich af te zetten tegen het regime om hun autonomie te behouden. Binnen de unit hadden de gedetineerden een grote mate van zeggenschap over hun dagbesteding, de inrichting van hun cel en unit, en de huisregels. Verder waren er zeer beperkte restricties omtrent de ontvangst van bezoek, waardoor bezoekers ook deel uitmaakten van het sociale leven in de unit. Bij overtreding van de huisregels werden gedetineerden gedwongen om verantwoording af te leg-

59 J. Bird, 'Spatial autonomy in penal settings. Case study: The Barlinnie Special Unit (1973-1994)', in: Hart \& Van Ginneken (red.) 2017.

60 Bird 2017.

61 Bird 2017.

62 Bird 2017, p. 132. 
gen aan hun medegedetineerden, die vervolgens konden beslissen over de consequenties.

Een ander voorbeeld van een gevangenisregime waarin de gemeenschap deels normbepalend en -handhavend is, is de therapeutic community (TC). ${ }^{63}$ In Engeland en Wales bestaat de mogelijkheid voor een select groepje gemotiveerde gedetineerden om de rest van hun straf in een TC door te brengen, waar resocialisatie centraal staat. Een TC-regime wordt gekarakteriseerd door gemeenschappelijke activiteiten, bijeenkomsten en psychotherapie (in groepen en individueel). Bewoners zijn gezamenlijk verantwoordelijk voor het succesvol functioneren van de gemeenschap en worden ook betrokken bij beslissingen over verlof, activiteiten in de TC zoals ouder-/kinddagen, en de verdeling van taken en baantjes. Daarnaast kunnen bewoners advies geven aan personeel over de toekomst binnen de TC van gedetineerden die de regels hebben overtreden of grenzen herhaaldelijk hebben opgezocht. Stevens beschrijft hoe deze verantwoordelijkheden bijdragen aan een positief zelfbeeld, maar ook aan de gepercipieerde legitimiteit van het regime en het gevoel rechtvaardig behandeld te worden. Bewoners waren hierdoor ook gemotiveerd om de regels na te leven. Stevens zegt hierover:

'By open communication in community meetings and by contributing to the enactment of justice and fairness in commitment votes, residents could therefore acquire a personal obligation to adhere to these democratically endorsed, communally "owned" decisions and standards; an obligation which was more easily and more keenly felt than that demanded by any number of rules and regulations imposed by prison governors. (...) The internalization of the very specific Durkheimian "collective conscience" that the TC engendered (...) ensured that, over time, most residents genuinely wanted to "obey" and comply with the social conventions, rules, expectations, obligations, and "whole new way of dealing with things" they found within their community.'64

Ook in Nederland wordt al geëxperimenteerd met zelfredzame afdelingen (zoals beschreven in de paragraaf 'Vrijheid en verantwoordelijkheid in detentie') waar gedetineerden meer vrijheden hebben om hun dag in te delen en grotere verantwoordelijkheid hebben in hun werkzaamheden. In de afwezigheid van constant personeelstoezicht ontstaat ook hier een vorm van sociale controle door gedetineerden. De volgende observatie heeft betrekking op de pilot met een zelfredzame afdeling in de penitentiaire inrichting Heerhugowaard:

'Vanwege de groepsdynamiek ontstaan er eigen regels op de afdeling. Zo kent de afdeling één roker die in overleg met de groep netjes de deur dicht houdt bij het roken. Ook wordt er gegeten wat de pot schaft en is er één gedetineerde die dagelijks het koken op zich neemt. Verwacht wordt dat iedereen 
voor het eten aan tafel zit en iedereen legt wat geld bij om lekker te kunnen eten.' 65

De regimes zoals hiervoor beschreven leiden niet noodzakelijk tot een minder zware detentie-ervaring. Integendeel, autonomie en vrijheid kunnen ook als last worden ervaren, omdat de verantwoordelijkheid voor eigen gedrag zwaar op de schouders kan drukken. ${ }^{66}$ Daarnaast kan het voor verwarring zorgen omtrent de rol van gedetineerden, verwachtingen over hun gedrag, en de relatie met personeel. De Barlinnie Special Unit en therapeutic communities hadden ook te maken met uitstroom van gedetineerden die niet in dergelijke omgevingen konden functioneren. Dit geeft aan dat er bij een detentievorm met een grotere mate van zelfbestuur ook aandacht zal moeten zijn voor zogeheten niet-kunners (en nietwillers). Het uitgangspunt voor het bepalen van het meest geschikte regime zou echter in eerste instantie veiligheid, conform het beginsel van minimale beperkingen, moeten zijn.

Het ondersteunen van gedetineerden bij het verantwoordelijk omgaan met vrijheid vereist een persoonsgerichte aanpak, waarbij inzicht is in de capaciteiten van gedetineerden en waarbij personeel bereid is om meer van de zijlijn toe te kijken. In de proeftuin 'Centrale voorziening' in de penitentiaire inrichting Vught bleek een dergelijke coachende aanpak goed te werken; repressie en beheersing maakten plaats voor gesprekken over gedragsnormen en -waarden tussen personeel en gedetineerden. ${ }^{67}$ Daarnaast is kleinschaligheid van de leefgemeenschappen binnen detentie een waarschijnlijke succesfactor voor het slagen van een dergelijke benadering. In relatie tot capaciteitsverschillen zou geen onderscheid gemaakt moeten worden tussen gedetineerden in, bijvoorbeeld, toegang tot bepaalde cursussen of bezoekuren. Wel kan er, met het oog op veiligheid, onderscheid gemaakt worden in het soort taken dat men kan vervullen en vrijheden om zich door (en buiten) de penitentiaire inrichting te bewegen. Tot slot zouden willekeurige belemmeringen voor zelfredzaamheid moeten worden weggenomen, zoals de financiële drempel om zelf te koken.

Het zelfstandig of in een groep bereiden van maaltijden is een voorbeeld van zinvolle tijdsbesteding die bijdraagt aan de ontwikkeling van zelfredzame vaardigheden, onderlinge sociale relaties en autonomie. ${ }^{68}$ Gedetineerden zouden aangemoedigd kunnen worden om zelf te koken en daarin ook begeleid kunnen worden (bijvoorbeeld door kookworkshops aan te bieden). In een kleine leefgemeenschap kunnen taken verdeeld worden, waardoor gedetineerden samen verantwoordelijkheid dragen voor het doen van inkopen en het bereiden van maaltijden. Daarnaast is het gezamenlijk nuttigen van een maaltijd een sociale activiteit die het gemeenschapsgevoel kan versterken. Dit voorbeeld geeft echter ook aan dat de grens tussen autonomie en paternalisme moeilijk te bepalen is: zelf koken en

66 V.L. Shammas, 'The pains of freedom: Assessing the ambiguity of Scandinavian penal exceptionalism on Norway's Prison Island', Punishment \& Society 2014, 1, p. 104-123.

67 Farahi \& Van De Rijt 2016

68 Farahi \& Van De Rijt 2016; L.K. Minke, 'Cooking in prison - from crook to cook', International Journal of Prisoner Health 2014, 4, p. 228-238. 
samen eten zijn vormen van sociaal gewenst gedrag die niet per se door iedereen onderschreven worden, noch in de vrije maatschappij verplicht opgelegd worden. Vorenstaande suggesties dienen vooral opgevat te worden als invulling van het beginsel van minimale beperkingen. Zelfredzaamheid en autonomie zijn namelijk geen panacee voor resocialisatie: hiervoor zal meer aandacht nodig zijn voor de omstandigheden van gedetineerden buiten detentie, waaronder hun sociaal en economisch kapitaal. Gezien de nadruk die er ook in de (participatie)samenleving op zelfstandigheid wordt gelegd, is het van belang meer aandacht te besteden aan beperkingen in zelfredzaam vermogen. Verder is het wenselijk om ons begrip van autonomie in detentie te vergroten en hoe zich dit verhoudt tot zelfredzaamheid. De vrijheid van gedetineerden is per definitie beperkt, maar binnen de gevangenismuren is er veel variatie mogelijk in de mate van bewegings- en beslissingsvrijheid. 